\title{
Lumen
}

Selected Proceedings from the Canadian Society for Eighteenth-Century Studies

\section{The Hermitage: Late Gothic or Early Detective Fiction?}

\section{Lorna Clark}

Volume 23, 2004

URI : https://id.erudit.org/iderudit/1012192ar

DOI : https://doi.org/10.7202/1012192ar

Aller au sommaire du numéro

Éditeur(s)

Canadian Society for Eighteenth-Century Studies / Société canadienne d'étude du dix-huitième siècle

ISSN

1209-3696 (imprimé)

1927-8284 (numérique)

Découvrir la revue

Citer cet article

Clark, L. (2004). The Hermitage: Late Gothic or Early Detective Fiction? Lumen, 23, 165-178. https://doi.org/10.7202/1012192ar

Copyright (C Canadian Society for Eighteenth-Century Studies / Sociéte canadienne d'étude du dix-huitième siècle, 2004
Ce document est protégé par la loi sur le droit d'auteur. L'utilisation des services d'Érudit (y compris la reproduction) est assujettie à sa politique d'utilisation que vous pouvez consulter en ligne.

https://apropos.erudit.org/fr/usagers/politique-dutilisation/ 


\section{The Hermitage: Late Gothic or Early Detective Fiction?}

Wilkie Collins' The Moonstone (1868) has been called the first — and best - detective novel ever written. ${ }^{1}$ But a work by a little-known woman writer predates Collins' novel by thirty years and bears eerie resemblances to his work. The literary career of Sarah Harriet Burney is representative of her generation: her first novel came out in the fertile decade of the 1790's; her second contains a distinctly Gothic setting and subplot, which also shades her third, in which a repressive tyrant rules at the heart of the paternal mansion. Her last work is a collection of tales which contains her most powerful writing, in which elements characteristic of her earlier fiction are brought to fruition. One of these tales features a picturesque hermitage, a ruined country maiden, and a murder-mystery; it can be read in Freudian terms as a psychodrama which explores the after-effects of trauma. A generation before Collins, it develops conventions inherited from Gothic fiction in terms that anticipate, or even establish the grounds of, the genre of detective novel. It would also change the gendered genealogy of detective fiction. Granting Sarah Harriet Burney the title of 'mother' (rather than 'father') of the genre would challenge prevailing critical assumptions of its patriarchal origins.

The question of 'who wrote the first mystery story in English' is a challenge worthy of the analytical skills of master-detective Sherlock Holmes himself, whose best-selling adventures in the 1880's led to a fifty-year period in which the genre flourished, supported by a widening reading public and market forces which favoured its consumption as entertaining light literature. ${ }^{2}$ As with any search for origins, it all de-

1 Thomas S. Eliot, in his introduction to the 1928 Oxford University Press edition of The Moonstone, referred to it as 'the first, the longest, and the best of modern English detective novels,' echoing remarks first published in an essay in TLS (August 4,1927).

2 A useful account of the Golden Age of detective story (1914-39) when the numbers of 
pends, as Dennis Porter has remarked, on whether one takes 'the long or the short view' of the subject. ${ }^{3}$ The short view, as outlined in traditional literary histories, is likely to identify Edgar Allan Poe as the progenitor of the detective story, citing his The Murders in the Rue Morgue (1841) and other short stories as containing the 'recipes on which ninetenths of all subsequent detective stories have been based..$^{4}$ Other critics, noting that 'until there were real life detectives, there could be no detective stories,' point to the creation of a new police force in London in 1829 , and a crime-detection unit in $1842 .{ }^{5} \mathrm{~A}$ prominent role is assigned to Charles Dickens for creating the first professional detective in English fiction, ${ }^{6}$ while his friend, Wilkie Collins, is credited with inventing the genre. In The Moonstone (1868), Collins laid down the rules that would be followed for a century and showed the full potential of the form, in combining 'a narrative structure that is thoroughly subjective and unreliable with the characteristic action of all detective fiction: the restatement and restructuring in the present of a past event.. ${ }^{7}$ Although published twenty-five years before Freud, The Moonstone lends itself to

new titles published in the U.K. multiplied tenfold, and roughly one quarter of all new titles published in the U.S. could be classified as crime stories, is contained in Julian Symons, Bloody Murder: From the Detective Story to the Crime Novel: A History, 2nd ed. (Harmondsworth, Middlesex: Viking Penguin, 1985), p. 108, 17.

3 Dennis Porter, The Pursuit of Crime: Art and Ideology in Detective Fiction (New Haven and London: Yale University Press, 1981), p. 11.

4 Tage la Cour and Harald Mogensen, The Murder Book: An Illustrated History of the Detective Story, trans. Roy Duffell (London: George Allen and Unwin, 1971), p. 12. For a discussion of the classic ingredients, which include 'the murky atmosphere, the insoluble problem, the outré method, the incredible deductions, the adoring Boswell, and the gifted being who unravels the most difficult crimes,' see George Grella, 'Murder and Manners: The Formal Detective Novel,' Novel 4 (1970): p. 30-48; reprint in Dimensions of Detective Fiction, eds. Larry N. Landrum, Pat Browne and Ray B. Browne (Bowling Green, Ohio: Popular Press, 1976), p. 42.

5 Eric Quayle outlines the historical background in The Collector's Book of Detective Fiction (London: Studio Vista, 1972), p. 22.

6 Inspector Bucket makes a brief appearance in Bleak House (1852-53). Dickens' growing fascination with crime, mystery and detection is indicated by the fact that the novel he left unfinished at his death, The Mystery of Edwin Drood (1870), featured at its heart a possible murder, destined to remain unsolved.

7 Albert D. Hutter, 'Dreams, Transformations, and Literature: The Implications of Detective Fiction,' Victorian Studies (1975); reprint in The Poetics of Murder: Detective Fiction and Literary Theory, eds. Glenn W. Most and William W. Stowe (San Diego, New York and London: Harcourt Brace Jovanovich, 1983), p. 231. 
psychoanalysis ${ }^{8}$ with its suggestive symbolism of the secret drawer in the Indian cabinet, from which Rachel witnesses her priceless jewel being stolen by her lover in the night, with the resultant telltale stain on his nightshirt; the theft is perceived by many critics as a 'symbolic defloration. $^{9}$

Literary roots for crime stories have been traced back even further: to tales of tricksters and rogues, folk heroes such as Robin Hood and picaresque novels; to The Newgate Calendar and printed 'confessions' of condemned criminals; to Fielding's Jonathan Wild, Defoe's fictional autobiographies and Godwin's Caleb Williams; nay, even to Le Roman de Renard and Chaucer's Canterbury Tales, the Arabian Thousand and One Nights, and the Bible. ${ }^{10}$ A case has also been made for most of the essential elements being present in the strange tales of E.T.A. Hoffman, who published a quarter-century before Poe, but who draws on the same roots, the romantic movement and the Gothic tales of horror, finding hidden powers, secret connections and meanings in everything. ${ }^{11}$

But in this discussion of origins and progenitors for the genre of mystery or detective novel, no one has yet remarked a little-known novel of 1839 , which appeared fully thirty years before Wilkie Collins' masterpiece. This work bears such eerie resemblances to its more famous successor, that one could be forgiven for wondering if they may be more

8 The genre may draw strength, as psychoanalytic critics have remarked, on the intense curiosity aroused by the 'primal scene' of infancy, the 'secret crime' at the beginning: i.e. the murder represents parental intercourse, the parent is victim, and the clues 'disconnected, inexplicable, and trifling' are the child's growing awareness of incomprehensible details, such as the family sleeping arrangements, nocturnal sounds, and stains, etc. The first statement of this theory is in Geraldine Pederson-Krag, 'Detective Stories and the Primal Scene,' Psychoanalytic Quarterly 18 (1949): p. 207-14; reprint in Poetics, p. 13-20, especially p. 15-16. The theory is applied to The Moonstone in Hutter.

9 Hutter; Charles Rycroft, 'The Analysis of a Detective Story,' Psychoanalytic Quarterly 26 (1957): p. 229-45; reprint in Imagination and Reality, intro. M. Masud, R. Khan and John D. Sutherland (New York: International Universities Press, 1968), p. 114-28. See also Lewis A. Lawson, 'Wilkie Collins and The Moonstone,' American Image 20 (1963): p. 66. The quoted phrase is in Sue Lonoff, Wilkie Collins and his Victorian Readers: A Study in the Rhetoric of Authorship (New York: AMS Press, 1982), p. 210.

10 For literary roots in earlier eras, see Alma E. Murch, 'Early Sources of Certain Features of Detective Fiction,' chap. 1 of The Development of the Detective Novel (Port Washington, New York: Kennikat Press, 1968), p. 18-35.

11 Richard Alewyn, 'The Origin of the Detective Novel,' in Poetics, translated from his 1974 essay in Probleme und Gestalten in Poetics, p. 17-77. 
than merely coincidental, and for speculating that Collins may actually have known of and drawn on it, either directly or indirectly (whether consciously or not), as his inspiration. Written by a woman, the younger half-sister of Frances (Burney) d'Arblay, Sarah Harriet Burney (17721844 ), it provides a bridge from the Gothic to the mystery novel. Not only does it deserve the title, now usually accorded to The Leavenworth Case of Anna Katharine Green, published in 1878, of being the first full-length mystery story written by a woman in English, ${ }^{12}$ but in anticipating both Poe and Collins, its author should be accorded the role of 'mother' rather than 'father' of the genre. ${ }^{13}$ Detective fiction would thus acquire a female lineage and ancestry which would place it firmly in the female tradition of the novel.

The Hermitage is the second of two tales in Burney's last work, The Romance of Private Life. Published when she was 67, five years away from her death, she brings to it all the skills gathered throughout her writing life, making it her most powerful and intriguing fiction. In an idyllic pastoral setting, it starts as a comedy of manners, dealing with nothing more problematic than the marital and testamentary intentions and complications of a family of country gentry. Will the beautiful and spirited Ella be won over by the machinations of her scheming mother to marry a wealthy scion of a neighbouring estate, or heed the whisperings of her own heart in favour of the gentle but penniless orphan, the companion of her childhood, Ernest de Gray? Will her scapegrace brother Frederic be disinherited by his crotchety old uncle? Add in a comically pedantic and absent-minded aunt, a bluff country squire, a modest vicar's daughter and a few dinner guests, and the recipe appears complete.

However, a serpent enters the Garden of Eden; a humble maiden, the dazzlingly beautiful Ruth, has apparently turned the heads of both young men. One sultry day, Ella overhears a heated quarrel between them, after which she sees Ernest gallop away. She enters the hermitage to find her brother apparently fallen asleep. In fine detail, the narrative recounts the macabre scene, as the heroine first imprints a kiss on his cold forehead, then fondles his lifeless hand, and finally feels his heart; she is horrified, on withdrawing her own hand, to find it steeped in blood, just as she perceives in a flash of lightning, Ernest de Gray's Indian

12 E.g. Murch, p. 158 cites Anna Katharine Green (1846-1935), as 'the first woman to write a full-length detective story.'

13 As in Quayle, p. 90. 
stiletto, still reeking from the dastardly crime. She shrieks and swoons, weltering in a stream of blood; her screams rend the air, shattering the peaceful pastoral, and ushering in a new form of fiction.

The discovery of an incongruous corpse in The Hermitage is the incident on which the narrative turns ('not in my grounds surely!' comments Sir Ormond); its development and effects were to become conventional. As a transgressive crime, the discovery shatters the peace of this rural society, and transforms the family which erupts into disorder (or perhaps it simply exposes the decay already inherent in the institution) ${ }^{14}$ Moreover, the victim himself is one who has also transgressed and threatened the social order. It is often said that the murder disposes of a victim whom society is better off without, who has in some (either minor or major) way, violated social norms and laws. This is certainly true of Frederic Ormond, who, it transpires, has treacherously seduced the beautiful maiden, who will soon bear the signs of her shame. Ernest de Gray, in trying to bring him to a proper sense of his responsibilities, has become the object of his ire, and the quarrel between them apparently ends fatally.

The Gothic elements in the tale are striking and recall an earlier era. Early on, the reader is introduced to the hermitage of the title, which, if not quite a picturesque ruin, is at least a rustic retreat, surrounded by mossy seats and hallowed by memories of childhood. There are scenes of pathetic fallacy, in which the heroine gazes out the window or rambles dejectedly in the landscape; her despondent thoughts when she is forced by the tragic turn of events to leave her childhood haunts evoke Radcliffe's Emily St. Aubert. The Indian stiletto, with its mysterious and sinister engravings, is introduced in a splendid scene evoking the Arabian nights; these allusions to the exotic east would later be elaborated by Collins with the mystical legend of the moonstone and its curse.

The setting and overtones are no surprise to those familiar with this writer's work. Born in 1772, Sarah Harriet Burney is a figure who spans both centuries and can be seen to prefigure, even to anticipate, literary

14 Elizabeth Rose Gruner, in 'Family Secrets and the Mysteries of The Moonstone,' Wilkie Collins, p. 221-43, relates the plot to a real-life murder case and 'suggests that the mysteries of both are based on the family's impulse to conceal, and on the secrecy which is integral to the nineteenth century conception of privacy. The sensation novel's peculiar obsession with skeletons in the family cupboard - indeed, its tendency to represent the family as nothing but a cupboard of skeletons - has preoccupied commentators ever since the 1860's,' Lyn Pykett, 'Introduction,' Wilkie Collins, ed. Lyn Pykett (New York: St. Martin's Press, 1998) p. 21. 
developments of the nineteenth century, bringing into them the heritage of an earlier era. Her first novel was published in the 1790's, that 'decade of Gothic fiction', ${ }^{15}$ it has a motif of fraternal incest and doubled characters suggesting a form of repetition-compulsion. Her second includes a Gothic subplot and a familiar confrontation between the heroine and a hidden portrait which holds the key to her identity. ${ }^{16}$ Her bestseller, Traits of Nature (1812), was written at the high point of the Gothic, and features a patriarchal tyrant persecuting a passively virtuous heroine. Another tale, Country Neighbours (1820), shows a haughty patriarch ensconced in a gloomy castle; again a hidden portrait exerts a potent influence.

It is possible that The Hermitage was begun soon after and intended as part of this earlier series of tales (the first third may in fact have been written almost twenty years before its actual date of publication), thus linking the two eras in an even more direct way. In 1814, Burney's publisher, Henry Colburn, 'one of the principal publishers of novels and light literature of his time, ${ }^{17}$ had invited her to contribute a short story to his newly launched periodical, the New Monthly Magazine. ${ }^{18}$ This suggestion Burney at first refused but later complied with, supplying him with two tales of an initially-promised four, under the running title of Tales of Fancy, for which she would be paid $£ 300$ a volume, if the first two were successful. ${ }^{19}$ Illness and other family crises intervened, but on 27 February 1821, Burney was hard at work on a third, when she wrote, 'My own trash stands stock still a little beyond p. 80. Un de ces beaux jours perhaps it may see light again. ${ }^{20}$

15 Fred Botting, Gothic (London and New York: Routledge, 1996), p. 62.

16 See George E. Haggerty's comment in Gothic Fiction / Gothic Form (University Park and London: Pennsylvania State University Press, 1989), p. 83: 'If we have any sense of the frequency with which ancestors step out of portraits in Gothic novels, we have no choice but to acknowledge Poe's immense pleasure in satirizing the genre.'

17 'Appendix,' Annual Register 97 (1855): p. 300.

18 Interestingly, Colburn's periodical, the New Monthly Magazine 'published several articles about Mrs. Radcliffe, including a posthumous fragment. Colburn also had a circulating library which reprinted many of the old Gothick titles during this period,' Victor Sage, 'Introduction,' The Gothick Novel: A Casebook, ed. Victor Sage (London: Macmillan, 1990), p. 20-21.

19 The Letters of Sarah Harriet Burney, ed. Lorna J. Clark (Athens, Georgia: University of Georgia Press, 1997), p. 179, 197.

20 Letters, p. 230-31. 
For a writer who was economical with her material (other than this reference, no works are mentioned in her letters besides those published), it is tempting to link this passage to a later one, in January 1838, when she laments that financial necessity, occasioned by an expensive illness, has driven her to complete and publish a partially finished earlier work:

I luckily had one little work quite ready, written at Florence, and another about one third finished. I took courage, \& completed it after my return, \& the two (making three volumes) are now in the hands of Colburn. The produce will set me clear, \& somewhat over. ${ }^{21}$

This work was The Romance of Private Life, published in 3 volumes in $1839,{ }^{22}$ again a set of two tales. The first two volumes comprise The Renunciation, a story set in Italy, whose progress, public reading and temporary setting aside can be followed through the family correspondence. ${ }^{23}$ Conjecturally, the second was the work begun and dropped many years earlier, which would account for a certain lack of continuity in some of the characters, such as a female companion who acts as foil to the heroine, introduced in the early chapters but who later disappears, only to be replaced by another completely new character who performs the same function. It would also explain certain discrepancies, such as the differing and somewhat conflicting accounts of the hero's childhood, which are given early and late in the tale. Thus, the evidence surrounding the composition of The Hermitage suggests that Burney may have returned to a work begun many years before, hence the atmosphere of an earlier era, and also that she may have altered her original plan - the murder occurs about half-way through - incorporating new literary influences to which she had by then been exposed.

Fiction had certainly moved forward since the series of tales published twenty years earlier. A few months before The Romance came out, she was recommending enthusiastically to her correspondents, that if they had 'time \& spirits' for a 'laugh' to peruse Sketches by Boz, which she praised for its 'wit \& humour.' The next year, she was still enjoying other 'delightful' works by Dickens, which she invariably described favour-

21 Letters, p. 419.

22 The completed manuscript was offered to Colburn on 14 November 1837 but its publication was delayed until September 1839 (Letters, p. 423, 425 n. 8).

23 Letters, p. 343 n. 4, 355, 357 n. 15, 375, 378 n. 4, 409. 
ably as 'lively' and 'amusing. ${ }^{24}$ Indeed, judging by the number and kind of references in her letters, Dickens seems to have joined the select few of her favourite authors, an honour reserved in earlier decades for the likes of Maria Edgeworth, Sir Walter Scott and Jane Austen. It is tempting to speculate, though here without foundation, that had their generations been aligned, Burney may well have been among the female writers encouraged by Dickens (as were George Eliot and Mrs. Gaskell) to supply material for his periodicals.

Burney, then, knew of Dickens' work; even more surprising is the fact that her own work introduces elements which, reappearing some thirty years later in the detective fiction of Wilkie Collins, were to prove so influential on the future development of the genre. In her tale, The Hermitage, the most remarkable thing about the murder, is not so much the attempt to discover who committed it; at first reading, the reader assumes, as does the heroine, to whose thoughts s/he is privy, that it has been committed by her lover, Ernest de Gray. It is Ella's reaction to the crime which is the focus of the narrative, the effects of her suppressing knowledge of his guilt, her hiding a secret of such enormity, which is traced with subtle psychological insight.

Pleading to be left alone with the corpse, Ella retrieves the bloody dagger (that phallic symbol) and, to protect her lover, secretes it on her person, and disposes of the weapon in a nearby pond. Only then does she return to her room, remove her blood-soaked clothing and collapse on the bed, where 'with clasped hands and tearful eyes, [she] lay mournfully meditating,' a position from which she will not rise for months, victim of a nearly fatal illness which threatens her life and reason, in a form of post-traumatic depression:

The malady was long, and its result frequently dubious; but throughout its whole course she never for a moment fell into a state of raving and incoherency. Often speechless, and reduced to the feebleness of an infant, she uniformly preserved her consciousness; and during the many many lingering hours that infirmity condemned her not only to spend in bed, but to lie in the same posture, incapable of turning herself, her senses continued unimpaired, and were employed in silent prayer. ${ }^{25}$

24 Letters, p. 439, 440.

25 Sarah Harriet Burney, The Hermitage, vol. 3 of The Romance of Private Life (London: Henry Colburn, 1839), p. 168. All further references to this work appear in the text. 
Throughout the debilitating fever, she resists falling into delirium, for fear that she should implicate her lover with a careless word, though she cannot bear him in her sight. She maintains a grim hold on her consciousness, paying the price for this ruthless self-suppression and internal conflict with a complete breakdown, which irreparably changes her looks and personality.

Ella retreats to a private space where she remains locked within herself; her silence and immobility, the wide-eyed stare, is a powerful image for passive female suffering. I have suggested elsewhere that this image is 'somehow emblematic of the female condition' in Burney's fiction, 'the ultimate extension of the forces' which she shows at work in a patriarchal society. ${ }^{26}$ Unable to bear too much reality, Ella shrinks from her exposure to sin, the fruit of the tree of knowledge, and expresses her desire to return to the womb-like security of childhood in a temporary regression to a form of stasis, lying motionless on the bed. 'The secret,' or guilty knowledge which she suppresses (which, interestingly, is the subtitle of another of her tales), ${ }_{1}^{27}$ is clearly sexual in content, akin to that of Rachel Verinder who, too, represses her belief in her lover's guilt, illogically neither accusing him nor ceasing to love him, her irrational behaviour and ambivalence being interpreted as evidence of a 'symbolic seduction. ${ }^{28}$

What Ella sees and discovers when left alone in The Hermitage with her brother's body, an encounter from which she emerges harrowed and bloodied, changes her forever. Representing the complete loss of innocence, it closes the gates of her childhood behind her and initiates her in a rather traumatic way, in a rite of passage into adulthood. The text contains sexual undertones throughout, for instance, a hint of sibling incest in Ella's demonstrative affection for her handsome brother. Simi-

Lorna J. Clark, 'Sarah Harriet and Frances Burney: The Novels in the Family and the Family in the Novels,' a paper presented at the Burney Society Conference, Celebrating Frances Burney, in Westminster Abbey, London, 13-14 June 2002.

27 'Elaine Showalter believes that "secrecy was basic to the lives of all respectable women" of the mid-nineteenth century. ... But the secrecy ... becomes dangerous in The Moonstone when it becomes epidemic, as the women who in concealing their passions also conceal a crime and set off a chain of circumstances which includes theft, suicide, and murder. The family's reliance on secrecy for its normal maintenance quickly translates, in The Moonstone, into an almost pathological - and certainly criminal - secrecy,' Gruner, p. 227-28, citing Elaine Showalter, 'Desperate Remedies: Sensation Novels of the 1860s,' Victorian Newsletter 49 (1976), p. 2. 
larly, there is a suggestion of fratricide in the eerie sojourn with the lifeless corpse from which Ella emerges, irreversibly violated in mind and body; her only conscious act thereafter is to submerge the bloodied instrument in the waters of the deep, in a sequence which lends itself to a Freudian interpretation.

But the patterns of silence in this novel are even more complex, for the motif is doubled, suggesting some form of 'repetition-compulsion. ${ }^{29}$ The hero, Ernest, whose sensitive feminine nature has been stressed, is silent from the same motives as Ella; he also hides secret knowledge, the guilt, which he has inadvertently discovered, of another, whose identity he protects. In a climactic scene, Ella appeals to him to exonerate himself from her suspicions, to 'pronounce but this short sentence: "I am innocent"' (p. 219). Ernest, however, leaves the room in silence, the desired words unspoken and departs on his travels. When he returns, he remains passive before his accusers, and is on the point of being charged when the murderer confesses, thereby exonerating him.

Both Ella and Ernest, then, are intrinsically connected, taking onto themselves the burden of guilty knowledge in their society, enacting these hidden sins on their own bodies. As scapegoat figures, they undergo the purgatory of suffering, Ella in her catatonic trance, and Ernest as the alienated wanderer, until the period of expiation is over and the truth can set them free. When the way is paved for their union at the end, it heralds a new order of society and reconstitution of the family group, cleansed of evil (with the villains, both murderer and victim cast out), and based solidly on tempered affection, proven and true. The novel thus sustains a reading which links it to the catharsis of Greek tragedy, or even a figuring of the Christian myth. ${ }^{30}$ It also represents (in extreme

29 Extracts from Sigmund Freud's influential article first published in German in Imago 5, 1919 and reproduced as 'The Uncanny,' translated by Alix Strachey in Collected Papers of Sigmund Freud (London, 1957), reprinted in The Gothick Novel, ed. Sage, p. 85.

30 The crime story has been related to Greek tragedy, in that it provides a 'release from anxiety in the identification of the scapegoat-criminal' and draws its strength from 'the dialectic of innocence and guilt.' When the 'demonic pride' of the murderer is chastised and he is cast out from society, his 'expulsion has a cathartic effect, liberating the reader's own latent hubris and guilty desires.' (This has been used as an explanation for its popularity reaching its zenith in the 1920's and 30's when the world was 'ridden by an all-pervasive feeling of guilt and by a fear of impending disaster'). See the classic essays of Edmund Wilson, 'Why do People Read Detective Stories?' The New Yorker 14 October (1944), p. 76, and Wystan H. Auden, 'The Guilty Vicarage,' The Dyer's Hand and Other Essays (New York: Random House, 1948), both cited in Grella, p. 87. 
form perhaps) the female novel of education, the heroine's coming of age and her initiation into the knowledge and experiences (including sexual) necessary to fit her for adult life.

This is, however, a complex novel; at another level, a different reading is possible. The doubling of characters, motifs and situations occurs throughout, interwoven in a complex pattern. The parallelisms and similarities are suggestive of self-division and the existence of repressed desires. As in Dickens, where Steerforth acts as the surrogate for David Copperfield's subconscious urges, or in Collins, where Godfrey Ablewhite, Rachel's would-be suitor, receives and disposes of her precious jewel from her true lover (perhaps carrying out his unacknowledged wishes), so the doublings and pairings in The Hermitage blur the question of guilt and innocence and implicate the lovers in the central action of murder.

The murderer and victim(s) (more than one, for Ruth too later kills herself) may be read as alter-egos of the two principals, or projections, acting out their subconscious impulses. The suggestion of a love triangle and apparent rivalry between Ernest and Frederic over Ruth is never fully repudiated. Regarded as twin facets of the same character, the two young men are inextricably connected: 'Seen so continually together their age the same - their footing in the family so nearly equal, ... [they] might have been considered as brothers' (p. 176).

There is also a hidden connection between Ella and Ruth - a physical resemblance in the dark hair, lovely face and comely figure common to both. Their initial descriptions (p. 10-15; p. 83-84) present Ella as a younger sister or self, emphasising her extreme youth and kitten-like playfulness. She appears to be a more innocent inscription of the same material. Ruth from the outset is more womanly and imposing, enigmatic in her beauty; she seems already in possession of secret knowledge even on their first encounter.

The connection between Ernest and Wilfred, Ruth's rustic lover who avenges her wrongs in a jealous rage, is also strong (the murder being committed by a lower-class man later becomes a convention). It is Ernest who provides the means (Wilfred is in Ernest's bedroom, when he discovers the weapon), the occasion (the quarrel with Frederic, overheard by Wilfred) and the opportunity (by leaving Frederic alone in the hermitage).

The connection between hero and murderer as single aspects of a divided self is evident in other ways: they are soul-brothers, foster-children, nurtured by the same nurse. Ernest is present when Wilfred confesses; he vows to conceal what he has learned, and even condones the crime. His involvement gives added resonance to his refusal to assert 
his own blamelessness. His sense of culpability expresses the generalised sense of guilt and anxiety familiar from the Gothic. ${ }^{31}$

It is undeniable that the murder works out most fortunately for de Gray in disposing of a rival, who stood in the way of both his love and his prosperity; the elimination of Frederic wins him both a fortune and the woman he desires. Frederic's death leads to the estate being divided between hero and heroine with a clause to encourage their marriage. Ernest changes his surname, thus displacing Frederic both literally as well as figuratively as heir. Frederic's bitter accusation that de Gray is aiming to supplant him drives Ernest - and the eavesdropping Wilfred - to a frenzy, thus sealing his fate. This beneficial outcome sheds new light on the two 'secret sharers' in the mystery, in their suppression of crucial information - she, in concealing the weapon, and he, the identity of the murderer.

The strong family endorsement and cash incentives are the only conditions powerful enough to persuade Ella's scheming mother to sanction the union. Early on, while cherishing in secret her low-born lover, Ella 'had no plan for the future - ... Time, she fancied, might do something for her; and to time she trusted' (p. 75). Her trust is indeed justified. In the fullness of time, the tragedy in the hermitage unfolds, removing the blockage of parental opposition. Murder is the means to fulfilment of her desire. The transgressive crime, then, appears to be contained within the structure of the comedy of manners (as some theorists of the detective novel have suggested), ${ }^{32}$ and may be seen as no more than a device to ensure that the path of true love runs smooth. Within months of the purging murder, the rural society emerges purified, celebrating a happy union which will ensure a prosperous future. There is even a hint that like Esther Summerson or Anne Elliot, Ella begins to recover her looks.

The Hermitage of Sarah Harriet Burney is a complex novel in which Burney brings the elements in her earlier fiction to culmination. In it, we see the detective novel in its infancy, showing clearly the marks of its ancestry, as well as the seeds of its future development. In its psycho-

31 See Leslie Fiedler, 'The Substitution of Terror for Love,' The Gothick Novel, ed. Sage, p. 130-39.

32 The classic who-dun-it has been aligned with Austen and the comedy of manners in its setting amidst a group of upper-class characters, a stable and homogenous society, from which the murderer (as alazon figure) and the victim (as blocking character, or social undesirable) are expelled, leading to a ritual comic celebration of the restoration of social order at the end. See Grella, p. 88, 94 and passim. 
logical acumen and subtlety, Freudian associations, and containment of the central mystery within the structure of both comedy and tragedy, she provides some of the elements which later would be used to good effect by Collins and others, proving influential on the future development of the genre. There are aspects which do not fit, most notably, that there is no detective: the prosecution is carried out in a rather awkward way by a distant relative, heir to the estate, and the murderer is only brought to light (somewhat too conveniently) by his own long delayed (and insufficiently motivated) confession.

A last point worth mentioning is an intriguing focus on the 'bad mother' in the pattern of troubled family relations. Notably, there is no mention of the absent father of Ella and Frederic, nor any indication as to his character or fate. Curiously, blame for the death of Frederic comes to rest on inadequate mothering, for a variety of puzzling and sometimes conflicting reasons. In the last view of the happily reconstituted society at the end, Mrs. Ormond is banished from the communal happiness: hers 'was not a happy old age' (p. 339). It is difficult to see how Mrs. Ormond, absent for much of the action, bears so much of the responsibility, which leads one to wonder just what point Burney is making. In marked contrast to the patriarchal persecution characteristic of Gothic fiction, there is an increasingly matrilineal and matriarchal bent in Burney's later novels. ${ }^{33}$

This last point underlines the importance of according to this tale its rightful place in the early history of the genre, which would then acquire, rather than a paternal ancestry (Poe as 'grandfather'; Collins as 'father'), rather a maternal heritage. The gendered genealogy presented heretofore puzzles over how 'feminine genres are the matrix for the male-dominated detective novel ... [and how] the novel that "fathered" detective fiction resembles the female Gothic... ${ }^{34}$ But discovery of a 'mother' would dispel the confusion. Placed firmly in the female tradition of the novel, crime fiction can be seen to develop in a direct line from the Gothic, incorporating elements of domestic fiction and feminocentric novels of the late eighteenth century. Recognition of and serious critical attention

33 Lorna J. Clark, 'From the Margins to the Centre: The Spinster as Author, Narrator and Actor,' The Burney Journal 6 (2003): p. 36-55.

34 Tamar Heller, 'Blank Spaces: Ideological Tensions and the Detective Work of The Moonstone,' in Wilkie Collins, ed. Lyn Pykett (New York: St. Martin's Press, 1998), p. 245. See also Kathleen L. Maio, 'Had-I-But-Known: The Marriage of Gothic Terror and Detection,' The Female Gothic, ed. Juliann E. Fleenor (Montreal and London: Eden Press, 1983), p. 82-90. 
178 Lorna Clark

to Burney's The Hermitage as an early example would influence profoundly our understanding of the genre.

\section{LORNA CLARK}

Carleton University 